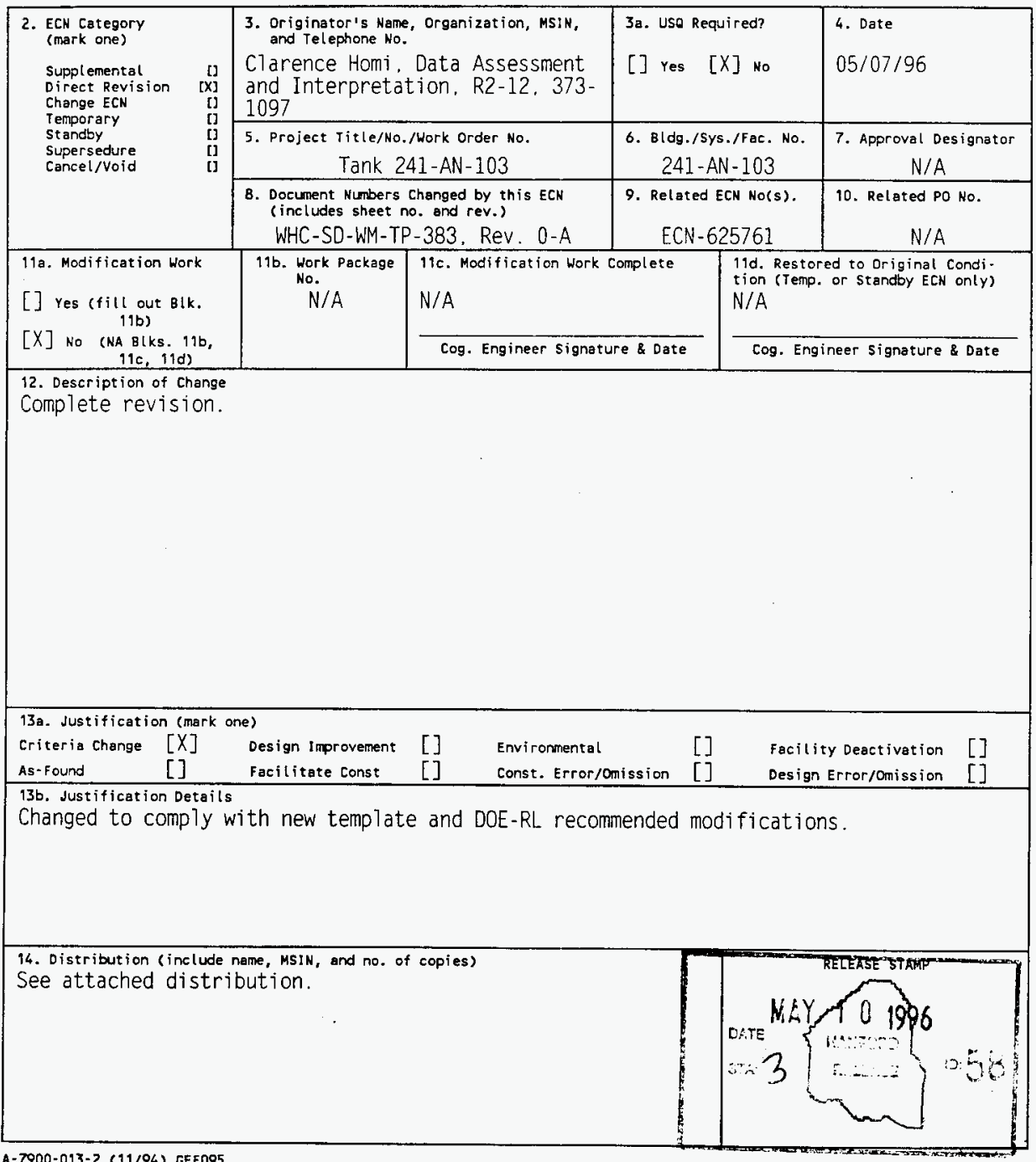




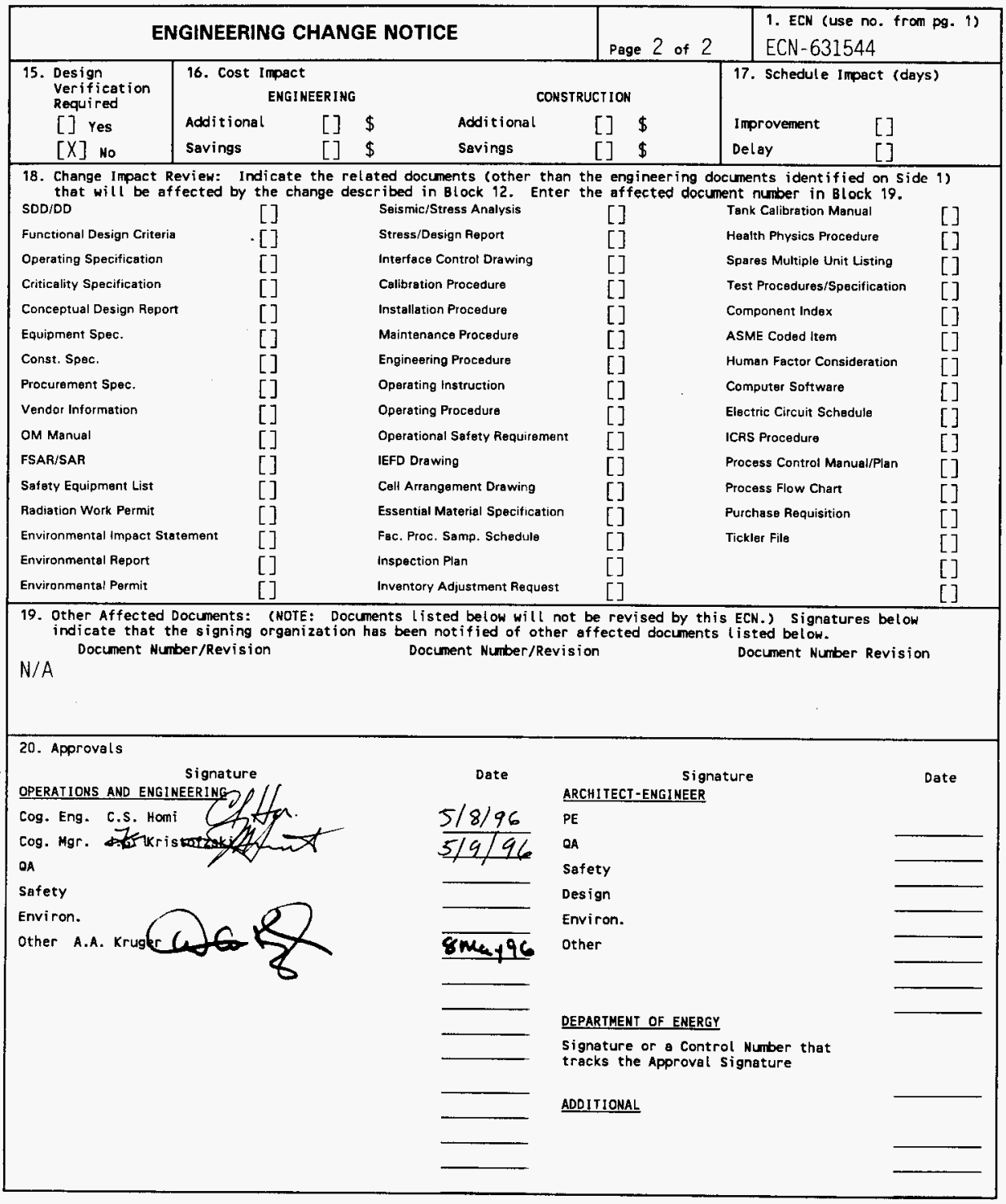




\title{
Tank 241-AN-103 Tank Characterization Plan
}

\author{
C. S. Homi
}

Westinghouse Hanford Company, Richland, WA 99352

U.S. Department of Energy Contract DE-AC06-87RL10930

EDT/ECN: ECN-631544 UC: 2070

Org Code: 79200 Charge Code: N4G6A

B\&R Code: EW 3120074 Total Pages: 9

Key Words: Characterization, General Safety Issues, Specific Safety Issues, Information Requirements, Schedule

Abstract: This document is a plan that identifies the information needed to address relevant issues concerning short-term and long-term storage and long-term management of double-shell tank 241-AN-103.

TRADEMARK DISCLAIMER. Reference here in to any specific commercial product, process, or service by trade name, trademark, manufacturer, or otherwise, does not necessarily constitute or imply its endorsement, recommendation, or favoring by the United States Government or any agency thereof or its contractors or subcontractors.

Printed in the United Stetes of America. To obtain copies of this document, contact: WHC/BCS Document Control Services, P.O. Box 1970, Mailstop H6-08, Richland HA 99352, Phone (509) 372-2420; Fax (509) 376-4989.
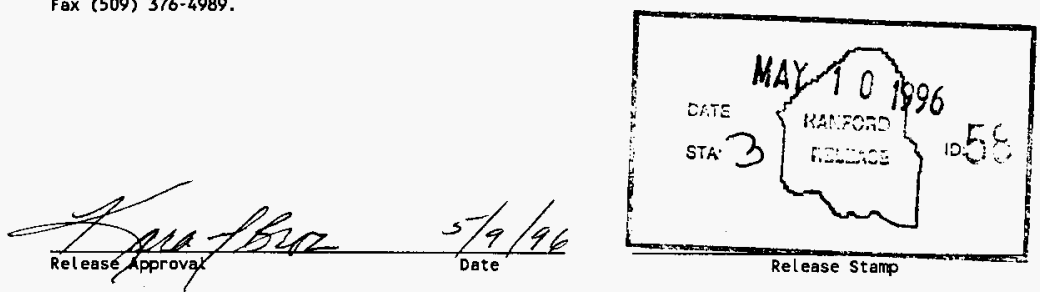

\section{Approved for Public Release}




\section{MECORD OF MIVISION}

(2) Tite

TAK 24l-AN-103 TAMK CHARACTERIZATION PLAN

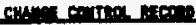

\begin{tabular}{|c|c|c|c|}
\hline \multirow{2}{*}{ (3) Revision } & \multirow{2}{*}{ (6) Deneription of Chenes - Replece, net, und Delote Pagen } & \multicolumn{2}{|c|}{ Athortred for belesen } \\
\hline & & (5) $\mathrm{Cel}$. Ener. & (6) $\mathrm{cos}$. \\
\hline 0 & $\begin{array}{l}\text { (7) } \\
\text { Aunust } 28,50-1995\end{array}$ & & $\cdot$ \\
\hline${ }^{O A}$ RS & $\begin{array}{l}\text { Added fl amable gas requirements, ECH } \\
625761\end{array}$ & & 4 \\
\hline 531 & Incorporate per ECN-631544. & C.S. Homi & Jakrjstofzski \\
\hline & & QDkn. & \\
\hline & & & \\
\hline & & & \\
\hline & & & \\
\hline & & & \\
\hline & & & \\
\hline & & & \\
\hline & & & \\
\hline & & & \\
\hline & & & \\
\hline & & & \\
\hline & & & \\
\hline & & & \\
\hline & . & & \\
\hline & & & \\
\hline & & & \\
\hline & & & \\
\hline & & & \\
\hline & & & \\
\hline & & & \\
\hline & & & \\
\hline & & & \\
\hline & & & \\
\hline & & & \\
\hline & $\cdot$ & & \\
\hline
\end{tabular}


WHC-SD-WM-TP-383

Revision 1

UC-2070

\title{
Tank 241-AN-103 Tank Characterization Plan
}

\author{
A. A. Kruger \\ Westinghouse Hanford Company \\ Date Published \\ May 1996
}

Prepared for the U.S. Department of Energy Office of Environmental Restoration and

Waste Management

\section{(Qv) Westinghouse \\ P.O. Box 1970 \\ Richland, Washington}

Management and Operations Contractor for the

U.S. Department of Energy under Contract DE-AC06-87RL10930

Approved for Public Release 


\section{WHC-SD-WM-TP-383 REV 1}

TABLE OF CONTENTS

1.0 INTRODUCTION 1

2.0 PROGRAM ELEMENTS REQUIRING INFORMATION FOR TANK 241-AN-103 1

2.1 GENERAL SAFETY ISSUES 1

2.2 SPECIFIC SAFETY ISSUES 2

2.2.1 Ferrocyanide 2

2.2.2 Organic 2

2.2.3 High Heat 2

2.2.4 Flammable Gas 2

2.2.5 Vapor 2

2.2.6 Criticality 2

2.3 CONTINUING OPERATIONS 2

2.3.1 Compatibility/Stabilization 2

2.3.2 Evaporator 3

2.4 DOUBLE-SHELL TANK WASTE ANALYSIS PLAN 3

2.5 DISPOSAL 3

2.5.1 Retrieval 3

2.5.2 Pretreatment/Vitrification 3

2.6 HISTORICAL MODEL EVALUATION 3

3.0 HOW INFORMATION WILL BE OBTAINED 3

4.0 PRIORITY OF INFORMATION REQUIREMENTS 4

5.0 WHEN INFORMATION WILL BE AVAILABLE 4

6.0 REFERENCES 5

LIST OF TABLES

Table 4-1 Integrated DQO Requirements and Priorities 4 


\section{WHC-SD-WM-TP-383 REV 1}

\subsection{INTRODUCTION}

This Tank Characterization Plan (TCP) identifies the information needed to address relevant issues concerning short-term and long-term safe storage and long-term management of double shell tank 24l-AN-103 (AN-103). It should be understood that the various needs and issues surrounding tank AN-103 are evolving as new information about the tank is uncovered. As a result of this progression, this TCP addresses only the issues that, to this date, have been identified. It is expected that deviations from this plan may occur as additional issues or needs arise which impact the management of tank AN-103. As necessary, this TCP will be revised as necessary to reflect those changes or deviations. This plan reflects the best information available as of May 1996.

Tank AN-103 was constructed in 1980 and entered into service in September 1981. The tank received non-complexed waste from tank 241-AN-102 unt il February 1984. During 1983, it received $7.6 \mathrm{~kL}$ (2 Kgal) of low-level waste from B-Plant and dilute non-complexed waste from the 200 East Area single-shell tanks. From March 1984 to April 1986, the tank received double-shel1 slurry feed. Tank AN-103 is currently inactive and holds concentrated waste (Brevick 1995).

Tank AN-103 currently contains a total waste volume of $3600 \mathrm{~kL}$ (95l kgal) which is equivalent to $881 \mathrm{~cm}(347 \mathrm{in})$ of waste, as measured from the baseline of the tank (Hanlon 1996).

This tank is on the Flammable Gas Watch List.

Near-term sampling and analysis activities are focused on either verifying or changing the Watch List tank status, and identifying any new safety issues. Should any safety issues be identified, additional analysis will occur consistent with the identified issue.

In addition to the resolution of the safety issues, it is intended that all tank waste will be subject to pretreatment and retrieval to prepare for final storage or disposal. Presently, these long-range plans have yet to be fully identified and are, therefore, not included in this document.

\subsection{PROGRAM ELEMENTS REQUIRING INFORMATION FOR TANK 241-AN-103}

This section identifies the various program elements, and identifies which of these programs require characterization data from tank $\mathrm{AN}-103$.

\subsection{GENERAL SAFETY ISSUES}

The Tank Safety Screening Data Quality Objective (Dukelow et al. 1995) describes the sampling and analytical requirements that are used to screen waste tanks for unidentified safety issues. Analytical requirements for the safety screening of a tank are energetics, total alpha activity, moisture content, density and flammable gas concentration. 


\subsection{SPECIFIC SAFETY ISSUES}

\subsubsection{Ferrocyanide}

This tank is not on the Ferrocyanide Watch List, therefore, no information needs are currently identified for this program element.

\subsubsection{Organic}

This tank is not on the Organic Watch List, therefore, no information needs are currently identified for this program element.

\subsubsection{High Heat}

This tank, is not on the High Heat Watch List; therefore, no information needs are currently identified for this program element.

\subsubsection{Flammable Gas}

This tank is on the Flammable Gas Watch List. The applicable data quality objective (DQ0) for this safety issue is: Flammable Gas Safety Program: Data Requirements for Core Sample Analysis Developed through the Data Quality Objectives Process (McDuffie 1995).

\subsubsection{Vapor}

A11 177 underground tanks must be vapor-sampled for organic solvent screening as per Recommendation 93-5 Implementation Plan (DOE-RL 1996). Some tanks may require additional vapor sampling due to other program needs. These tanks may be classified into four categories: (1) those tanks which are to be rotary mode core sampled (as a consequence of the rotary sampling system exhauster permit requirements); (2) tanks on the Organic or Ferrocyanide Watch Lists; (3) tanks in $\mathrm{C}$ farm; and (4) tank 241-BX-104, due to vapor exposure. Information needs must satisfy Data Quality Objectives for Tank Hazardous Vapor Safety Screening (Osborne and Buckley 1995), and for rotary mode only, Rotary Core Vapor Sampling Data Quality Objective (Price 1994), and Data Quality Objective for Regulatory Requirements for Hazardous and Radioactive Air Emissions Sampling and Analysis (Mulkey and Markillie 1995) as amended by Status of the Current Understanding of the Toxic Air Pollutants (TAPS) and Hanford Tank Farm Vapor Space Characterization; Recommended Path Forward and Justification for Continued RMCS Exhauster Operations (Laws 1996).

\subsubsection{Criticality}

No information separate from that for the general safety issue of tank AN-103 are currently identified for this program element. However, if the general safety screening of tank AN-103 identifies a potential criticality concern, analyses for fissile materials and neutron sorbers and poisons will be performed as identified in the safety screening DQO.

\subsection{CONTINUING OPERATIONS}

\subsubsection{Compatibility/Stabilization}

This section does not apply to tank AN-103. 


\subsubsection{Evaporator}

This section does not apply to tank AN-103.

\subsection{DOUBLE-SHELL TANK WASTE ANALYSIS PLAN}

Requirements for double-shell waste analyses are found in Double-Shell Tank Waste Analysis Plan (Mulkey and Jones 1995). This plan uses the compatibility (Fowler 1995) and safety screening (Dukelow et al. 1995) DQOs as the basis for identifying data requirements and criteria for the safe storage and mixing of wastes.

\subsection{DISPOSAL}

\subsubsection{Retrieval}

Current retrieval needs (Bloom and Nguyen 1995) do not call for test samples to be taken from tank AN-103.

\subsubsection{Pretreatment/Vitrification}

Tank AN-103 has not been identified as a bounding tank for pretreatment/ disposal process development strategy (Kupfer el a1. 1995). Al1 tanks were prioritized using the pretreatment strategy in the Tank Waste Characterization Basis (Brown et a1. 1995) document and a portion of archive sample material could be used for pretreatment testing if available. The strategy does not require any specific analyses be done on the samples.

\subsection{HISTORICAL MODEL EVALUATION}

Bounding tanks and data requirements for historical model evaluations are found in Historical Model Evaluation Data Requirements (Simpson and McCain 1995). Tank AN-103 is not identified as a primary bounding tank for historical model evaluations.

\subsection{HOW INFORMATION WILL BE OBTAINED}

The number of samples required to characterize a tank is a function of waste heterogeneity and the desired confidence to make a correct decision. As directed by the safety screening DQO, if inadequate information exists to determine an appropriate number of samples, two vertical profiles will be obtained. These vertical profiles may be obtained using core, auger (for shallow tanks), or grab samples. If analysis of these profiles reveals that additional profiles are necessary to meet data needs, more sample profiles will be requested. 
WHC-SD-WM-TP-383 REV 1

\subsection{PRIORITY OF INFORMATION REQUIREMENTS}

Push mode core sampling is scheduled for 0ctober 1996. Vapor sampling has not been scheduled as of April 1996 (Stanton 1996). Refer to Table 4-1 for the current $\mathrm{DQO}$ requirements and planned sampling and analytical requirements.

Table 4-1: Integrated DQO Requirements and Priorities

\begin{tabular}{|c|c|c|c|}
\hline $\begin{array}{l}\text { Sampling } \\
\text { Event }\end{array}$ & Applicable Issues & Sampling Requirements & Analytical Requirements ${ }^{*}$ \\
\hline $\begin{array}{l}\text { Vapor } \\
\text { Sampling }\end{array}$ & $\begin{array}{l}\text {-Organic Solvent Layer } \\
93-5 \text { Vapor Issue } \\
\text {-Hazardous Vapor DQO }\end{array}$ & $\begin{array}{l}\text { Steel canisters, } \\
\text { Triple Sorbent Traps, } \\
\text { Sorbent Trap Systems. }\end{array}$ & $\begin{array}{l}\text { Flammable Gas } \\
\text { Organic Vapors } \\
\text { Permanent Gases }\end{array}$ \\
\hline $\begin{array}{l}\text { Push Mode } \\
\text { Core } \\
\text { Sampling }\end{array}$ & $\begin{array}{l}\text { - Safety Screening DQO } \\
\text {-Flammable Gas DQO }\end{array}$ & $\begin{array}{l}\text { Core samples from } 2 \\
\text { risers separated } \\
\text { radially to the } \\
\text { maximum extent } \\
\text { possible (Grab samples } \\
\text { may be used to obtain } \\
\text { supernate. } \\
\text { Combustible Gas } \\
\text { Measurement }\end{array}$ & $\begin{array}{l}\text { Flammability, Energetics, } \\
\text { Moisture, Total alpha } \\
\text { activity, Anions, Metals, } \\
\text { Radionuclides, Density, } \\
\text { Physical properties, pH, } \\
\text { Total Organic Carbon, } \\
\text { Total Inorganic Carbon, } \\
\text { Cr(VI). }\end{array}$ \\
\hline
\end{tabular}

* Consult each applicable DQO in force at the time for sampling and analytical requirements.

\subsection{WHEN INFORMATION WILL BE AVAILABLE}

According to Stanton (1996) data are expected to be available from the push mode core sampling event for tank AN-103 in February 1997. This time may be altered if the sampling schedule changes. 


\subsection{REFERENCES}

Bloom, G. R. and Q. H. Nguyen, 1995, Characterization Data Needs for Development, Design and Operation of Retrieval Equipment Developed Through the Data Quality Objective Process, WHC-SD-WM-DQ0-008, Rev. 0 , Westinghouse Hanford Company, Richland, Washington.

Brevick, C. H., L. A. Gaddis, and W. W. Pickett, 1995, Historical Tank Content Estimate for the Southeast Quadrant of the Hanford 200 East Areas, WHC-SD-WM-ER-350, Rev. 0, Westinghouse Hanford Company, Richland, Washington.

Brown, T. M., S. J. Eberlein, and T. J. Kunthara, 1995, Tank Waste Characterization Basis, WHC-SD-WM-TA-164, Rev. 1, Westinghouse Hanford Company, Richland, Washington.

DOE-RL, 1996, Recommendation 93-5 Implementation Plan, D0E/RL-94-0001, Rev. 1, U.S. Department of Energy, Richland, Washington.

Dukelow, G. T., J. W. Hunt, H. Babad, and J. E. Meacham, 1995, Tank Safety Screening Data Quality Objective, WHC-SD-WM-SP-004, Rev. 2, Richland, Washington.

Fowler, K.D., 1995, Data Quality Objectives for Tank Farms Waste Compatibility Program, WHC-SD-WM-DQO-001, Rev. 1, Westinghouse Hanford Company, Richland, Washington.

Hanlon, B.M., 1996, Waste Tank Summary for Month Ending January 31, 1996, WHC-EP-0182-94, Westinghouse Hanford Company, Richland, Washington.

Kupfer, M. J., W. W. Schultz, and J. T. Slankas, 1995, Strategy for Sampling Hanford Site Tank Wastes for Development of Disposal Technology,

Laws, G. L., 1996, Status of the Current Understanding of the Toxic Air Pollutants (TAPS) and Hanford Tank Farm Vapor Space Characterization; Recommended Path Forward and Justification for Continued RMCS Exhauster Operations, (telephone conference memorandum, 01830-96-022, to Distribution, March 8) Westinghouse Hanford Company, Richland, Washington.

McDuffie, N. G., 1995, Flammable Gas Tank Safety Program: Data Requirements for Core Sample Analysis Developed Through the Data Quality Objectives (DQ0) Process, WHC-SD-WM-DQ0-004, Rev. 2, Westinghouse Hanford Company, Richland, Washington.

Mulkey, C.H., and K. D. Markillie, 1995, Data Quality Objective for Regulatory Requirements for Hazardous and Radioactive Air Emissions Sampling and Analysis, WHC-SD-WM-DQ0-021, Rev. 0, Westinghouse Hanford Company, Richland, Washington.

Mulkey, C. H., and J. M. Jones, 1995, Double-Shell Tank System Waste Analysis Plan, WHC-SD-WM-EV-053, Rev 3, Westinghouse Hanford Company, Richland, Washington.

Osborne, J. W., and L. L. Buckley, 1995, Data Quality Objectives for Tank HaZardous Vapor Safety Screening, WHC-SD-WM-DQ0-002, Rev. 2, Westinghouse Hanford Company, Richland, Washington. 


\section{WHC-SD-WM-TP-383 REV 1}

Price, D. N., 1994, Rotary Core Vapor Sampling Data Quality Objective, WHC-SD-WM-SP-003, Rev. 0, Westinghouse Hanford Company, Richland, Washington.

Simpson, B. C., and D. J. McCain, 1995, Historical Model Evaluation Data Requirements, WHC-SD-WM-DQ0-018, Rev. OA, Westinghouse Hanford Company, Richland, Washington.

Stanton, G. A., 1996, Baseline Sampling Schedule, Change 96-02, (internal memo 75610-96-06, to Distribution, Apri1 17), Westinghouse Hanford Company, Richland, Washington. 


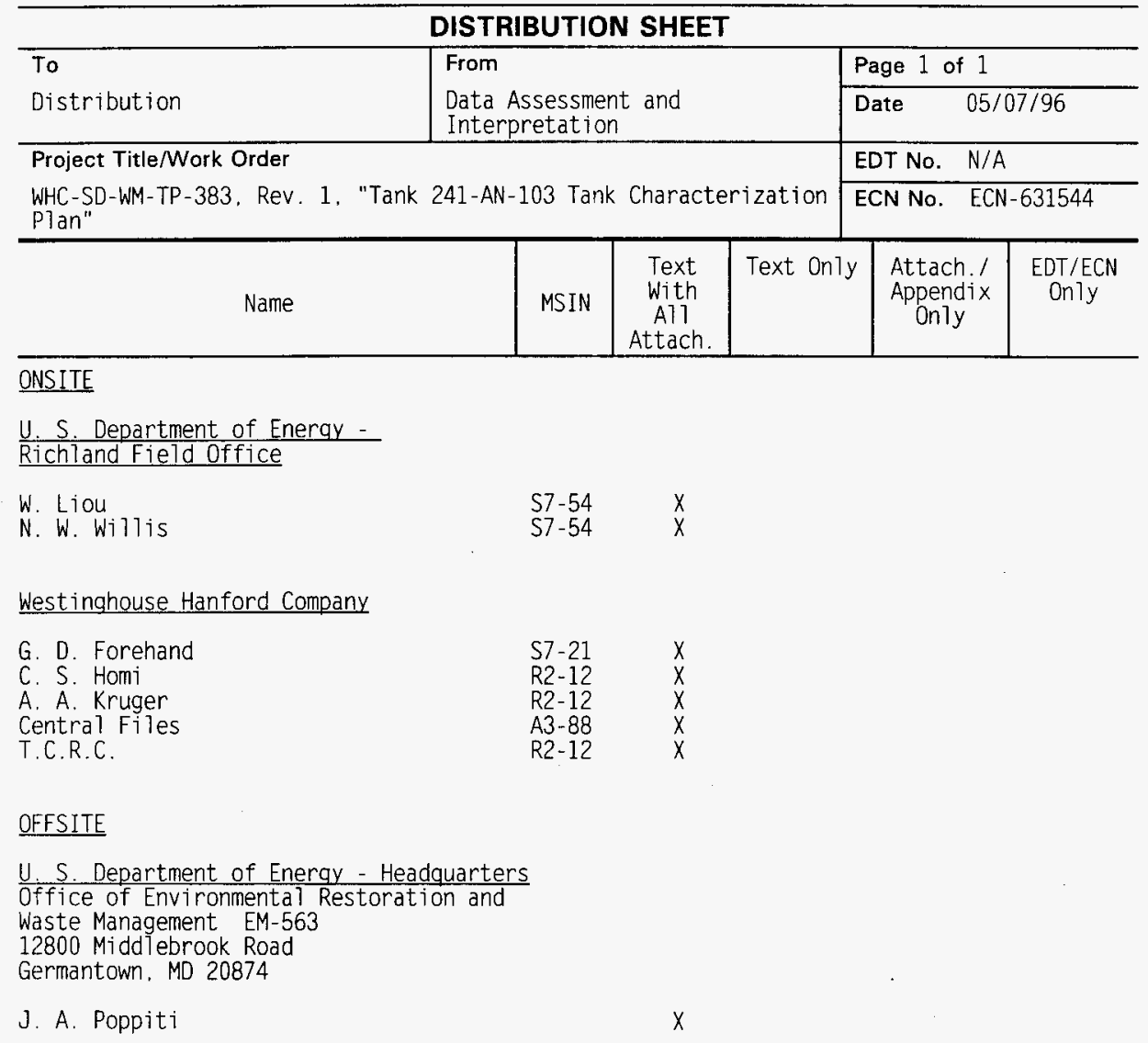

